\title{
Evaluation of Gaillardia (Gaillardia pulchella Foug) Genotypes for Loose Flower and Garden Display Purpose
}

\author{
Saniya*, Sateesh R. Patil, P. Pavan Kumar and Y. S. Mahesh \\ ${ }^{1}$ Department of Floriculture and Landscape Architecture, College of Horticulture, \\ Bagalkot-587 104, Karnataka, India \\ *Corresponding author
}

\section{A B S T R A C T}

Gaillardia (Gaillardia puchella Foug.) occupies one of the most important traditional flower in southern states of India, with respect to its commercial cultivation. The location specific cultivars are not available. This experiment was to evaluate the performance and

\section{Keywords}

Gaillardia, Garden display purpose, Genotypes

Article Info

Accepted:

17 January 2021

Available Online:

10 February 2021 adaptability of different gaillardia genotypes under Northern dry zone of Karnataka condition and to identify the best suitable genotypes for loose flower and garden display. For this purpose, a Randomized block experimental design with fifteen treatments and two replications was established. Based on the performance, the genotype UHSBGL-14 was identified to be superior with respect to growth and flower characters such as plant height $(52.29 \mathrm{~cm})$, Plant spread E-W \& N-S $(47.91$ and $48.32 \mathrm{~cm})$, Number of secondary branches/plant (27.75), early flower bud appearance(59.00 days), early 50\% flowering (69.05 days) flowering duration (131.00 days) and maximum shelf life. Genotype UHSBGL-10 recorded maximum flower disc diameter $(4.35 \mathrm{~cm})$ and highest individual flower weight $(8.99 \mathrm{~g})$ was recorded in UHSBGL-5. Number of flower/plant (203.30), and Flower yield/plant $(2.10 \mathrm{~kg})$ was also recorded maximum for the genotype UHSBGL-14. Highest scores for loose flower characters such as flower colour, size, shape and absence of disc and garden display characters such as, uniformity in growth, flowering and landscape impact were obtained for genotype UHSBGL-14 by consumer analysis.

\section{Introduction}

Gaillardia (Gaillardia pulchella Foug.) is commonly known as "Blanket Flower" because of its wide array of colours and patterns including Mexican blankets, gold tipped with russet-red centers but recent introductions have expanded the colour range. Gaillardia is also referred to as fire wheel or
Indian blanket or brown eyed susan in European countries (Helen et al., 2007). It is called as "Galatehoovu" and "saventige" in vernacular language of Karnataka. It is one of the important hardiest annual flower crop which belongs to the family Asteraceae with the basic chromosomes number of $\mathrm{x}=18$ and $2 n=36$ (Srivastava and Kandpal, 2006). It is native to Florida and western United States. 
The generic name of Gaillardia was proposed in honour of Gaillard de Marentonneau in $18^{\text {th }}$ century, a French supporter of Botany (Bailey, 1929).

It is a herbaceous annual or short-lived perennial growing up to a height of 30 to 150 $\mathrm{cm}$. Out of twenty species available in the genus, only Gaillardia pulchella is annual and Gaillardia aristata, is a perennial one in cultivation (Anon., 1950). The annual types grow to a height of 30 to $90 \mathrm{~cm}$. The leaves that appear in initial stages are large, up to15$20 \mathrm{~cm}$ length and more lobed than those that appear in the later stages. The characteristics such as leaf shape and size are highly variable in nature. Leaves may be basal and linear to lanceolate, grayish green and very hirsute.

The flowers of gaillardia are small and numerous; born in solitary, usually showy heads which is known as capitulam with 4 to $6 \mathrm{~cm}$ in diameter. Individual flowers in a capitulam are called as florets which range from one to ten according to cultivars or genotypes. As a member of Asteraceae family it has both ray and disc florets which are pistillate and hermaphrodite in nature respectively. The flower has a long hairy stalk and single, semidouble and double types with single or multicolored heads. The crop produces flowers in a wide range of colours such as yellow, orange, cream, scarlet, bronze, brick-red and red and can be grown all around the year.

\section{Materials and Methods}

The present investigation entitled "Evaluation of Gaillardia (Gaillardia pulchella Foug.) Genotypes for loose flower and garden display purpose" was undertaken at Department of Floriculture and landscape, College of Horticulture, Bagalkot during the year 2017-18.The experiment was laid out in simple randomized block design with two replication and fifteen treatments. Forty-five days old seedlings were transplanted on the main field with a spacing of $30 \times 45 \mathrm{~cm}$. Observations were recorded on five randomly selected plants in each replication at 30 days interval after transplanting upto harvest and sensory evaluation for consumer acceptance, for both loose and garden display was done using 5 point (Table 1) and 3 point (Table 2) hedonic scale respectively.

\section{Results and Discussion}

\section{Growth parameters}

The vegetative growth was measured in terms of plant height $(\mathrm{cm})$ per plant, number of secondary branches per plant, plant spread East-West and North-South $(\mathrm{cm})$ per plant and number of leaves per plant (Table 3).

Among the 15 genotypes evaluated, plant height was varied significantly in different genotypes throughout the experimental period (Table 3). The genotypes UHSBGL-14, UHSBGL-5, UHSBGL-3 and UHSBGL-10 showed vigorous growth in terms of plant height. The genotype UHSSBGL-4 recorded minimum plant height. Plant height being a genetically controlled factor, it varied among the genotypes as well as influence of the growing environmental conditions, production technology and cultural practices. Similar variation in plant height due to cultivars was also observed in gaillardia by Girange et al., (2016), Tamut (2013); Vikas et al., (2011) and Ajeetkumar et al., (2015) in dahlia; Namitha et al., (2008) and Narsude et al., (2010) in marigold.

Significant difference with respect to number of secondary branches produced per plant was noticed (Table 3). Number of branches was more in genotype UHSBGL-14 and UHSBGL-5, the genotype UHSBGL-4 recorded minimum branches. The difference in number of branches could be attributed to 
the genetic makeup of the cultivars. Increased number of branches leads to production of more number of leaves in turn it will enhance the yield of flowers and tubers by increasing source and sink relationship. Similar trend was noticed by Bhaskarwar et al., (2016), Girange et al., (2016), in gaillardia and Munikrishnappa (2013) in different genotypes of China aster.

Plant spread is an important growth factor for flower crops. It helps to utilize the sunlight to maximum extent. Plant spread during different growth periods varied significantly among the gaillardia genotypes (Table 3). Maximum plant spread was recorded in genotypes UHSBGL-5 and UHSBGL-14 throughout the growth period. This may due to more number of branches produced by these genotypes and vigorous growth character. Whereas, the genotype UHSBGL15 produced minimum plant spread and this may be due to varietal differences and less vigor in growth. Similar results were recorded by Tamut (2013) in gaillardia; Paru et al., (2011), Simrat et al., (2012) in chrysanthemum.

Significant differences were observed among the genotypes with respect to number of leaves per plant (Table 3). The maximum number of leaves per plant recorded in the genotype UHSBGL-14 whereas, minimum number of leaves per plant was recorded in UHSBGL-4. Since two characters number of branches and leaves are inter-related, the plants with the maximum number of branches are expected to produce the highest number of leaves because the leaves are the functioning units for photosynthesis on which growth and flower yield depend greatly. Variation in leaf production could also be attributed to genetic character of genotypes. These results are in conformity with that of Talukdar et al., (2006) in chrysanthemum and Vikas et al., (2011), Ajeethkumar et al., (2013) in dahlia.

\section{Flower parameters}

Flowering parameters includes number of days for first flower bud appearance, number of days taken for 50 percent flowering, duration of flowering, days to harvest and shelf life (Table 4).

Number of days taken for flower appearance of first flower bud is an important character that determines earliness or late flowering of the genotype, which determines the flower availability (Table 4). The genotype UHSBGL-14 took minimum number of days for appearance of first flower followed by UHSBGL-15 whereas, the genotypes UHSBGL-4 took maximum number of days. The variation in time taken for flowering may be dependent on the basis of the concept that proper amount of stored carbohydrates are necessary for inducing the plant from vegetative phase to flowering phase along with which genetic makeup and effect of environment on genotype also plays a vital role. Similar, variations were also reported by Bhaskarwar et al., (2016), Girange et al., (2016), Tamut (2013) in gaillardia; Singh et al., (2014), Bharthi and jwaharlal (2014); Chandrashekara et al., (2005) in marigold.

The genotype UHSBGL-14 took minimum number of days to reach 50 per cent flowering and it was on par with the genotype UHSBGL-15 whereas, genotype UHSBGL-4 maximum days for 50 percent flowering followed by UHSBGL-1 (Table 4). This could be attributed to the inherent early flower bud initiation factor which significantly influenced the days to $50 \%$ flowering. These results are in conformity with the reports of Girange et al., (2016), Tamut (2013) in gaillardia; Zosimliana et al., (2013) in China aster and Suma and Patil (2006) in Daisy.

Duration of flowering is highly economical and out most concerned character to growers 
as it decides the market demand, based on which we can chose the early or late flowering varieties (Table 4). With respect to flowering duration is concerned, the genotype UHSBGL-14 flowered for maximum duration followed by UHSBGL-15 whereas, minimum duration of flowering was found in UHSBGL4 followed by UHSBGL-1. The variation in flowering duration among the genotypes can be attributed to genetics of the plant, environmental influence, stored carbohydrates and other management factors. Similar results were reported by Bhaskarwar et al., (2016) in gaillardia; Chandrashekar et al., (2005), Narsude et al., (2016) in marigold and Deepa and Chezhiyan (2002) in chrysanthemum.

The genotype UHSBGL-1 took minimum number of days to harvest and it was on par with UHSBGL-4 (Table 4), whereas, genotype UHSBGL-5 took maximum days which could be attributed to genetic behavior of genotypes and number of whorls present in the flower more number of whorls present more of days required to reach harvesting stage as lose flowers are mainly harvested at full bloom stage. These results are in conformity with the reports of Girange et al., (2016), Tamut (2013) in gaillardia and Zosimliana et al., (2013) in China aster.

It is a parameter which decides the market distance, harvest chain handling system of any flower crop grown, (Table 4) the genotype UHSBGL-14 had maximum shelf life whereas, minimum shelf life was observed in genotype UHSBGL-1 followed by UHSBGL-3. This variation may be due to different genetic makeup of genotypes and influenced by prevailing environmental conditions which affect the physiological processes of flower like cell turgidity, water loss through evapotranspiration and break down of the reserve food which governs the shelf life of the flower. Similar results were noted by Bhaskarwar et al., (2016), Girange et al., (2016) in gaillardia and Chandrashekar et al., (2005), Narsude et al., (2016) in marigold.

Individual flower weight is ultimate factor on which grower is of out most concerned, In this study the average individual flower weight was highest in genotype UHSBGL-5 whereas, lowest flower weight was recorded by genotype UHSBGL-3. The variation among the genotypes was mainly because of increased flower size. Bhaskarwar et al., (2016), Girange et al., (2016) in gaillardia; Narsude et al., (2010), Raghuvanshi and Sharma (2011) reported similar results in marigold.

\section{Yield parameters}

All the parameter discussed above, ultimately contribute to yield, which is the most important to any grower, such as number of flowers per plant and flower yield per hectare (Table 5).

Significant differences were observed among the genotypes with respect to number of flowers per plant (Table 5). Maximum number of flowers per plant was produced in the genotype UHSBGL-14, followed by UHSBGL-5 and while least was in UHSBGL4. It may be directly related to the number of branches, leaves produced per plant, plant spread, rate of photosynthates produced in various genotypes. Similar results were reported by Bhaskarwar et al., (2016), Girange et al., (2016), Tamut (2013) in gaillardia; Patil et al., (2011) and Naik et al., (2005); Zosiamliana et al., (2013) and Munikrishnappa et al., (2013) in China aster. 
Table.1 Specific rating for loose flower purpose given below (Tamut, 2013)

\begin{tabular}{|l|l|l|l|c|}
\hline Flower colour & Flower shape & Flower size & \multicolumn{1}{|c|}{ Overall acceptance } & Score \\
\hline Attractive & Excellent & Excellent & Highly acceptable & $4.1-5.0$ \\
\hline Better & Better & Better & Moderately acceptable & $3.1-4.0$ \\
\hline Good & Good & Good & Acceptable & $2.1-3.0$ \\
\hline Average & Average & Average & Slightly acceptable & $1.1-2.0$ \\
\hline No attraction & Poor & Poor & Not acceptable & $0.1-1.0$ \\
\hline
\end{tabular}

Table.2 Specific rating for uniformity, flowering, and landscape impact given below (Helen et al., 2007)

\begin{tabular}{|c|c|l|c|}
\hline Uniformity & \multicolumn{1}{|c|}{ Flowering } & \multicolumn{1}{c|}{ Landscape Impact } & Score \\
\hline Low & No flower present & Negative aesthetic impact & $0-1$ \\
\hline Medium & $1-20$ percent flower present & Slightly positive aesthetic impact & $1.1-2$ \\
\hline High & $>20$ percent flower present & Highly positive aesthetic impact & $2.1-3$ \\
\hline
\end{tabular}

Table.3 Growth parameters in various genotypes of gaillardia

\begin{tabular}{|c|c|c|c|c|c|c|}
\hline \multirow[t]{2}{*}{ Genotypes } & \multirow[t]{2}{*}{$\begin{array}{c}\text { Plant } \\
\text { height }(\mathrm{cm}) \\
\text { per plant }\end{array}$} & $\begin{array}{c}\text { Number } \\
\text { of } \\
\text { Primary } \\
\text { branches } \\
\text { per plant }\end{array}$ & $\begin{array}{c}\text { Number } \\
\text { of } \\
\text { Secondary } \\
\text { branches } \\
\text { per plant }\end{array}$ & \multicolumn{2}{|c|}{$\begin{array}{c}\text { Plant spread } \\
(\mathrm{cm}) \\
\text { per plant } \\
(180 \text { DAT })\end{array}$} & \multirow[t]{2}{*}{$\begin{array}{c}\begin{array}{c}\text { Number of } \\
\text { leaves } \\
\text { per plant }\end{array} \\
\text { (180 DAT) }\end{array}$} \\
\hline & & \multicolumn{2}{|c|}{ (180 DAT) } & E-W & $\mathbf{N}-\mathbf{S}$ & \\
\hline UHSBGL-1 & 45.00 & 5.50 & 13.85 & 41.37 & 41.77 & 307.10 \\
\hline UHSBGL-2 & 44.86 & 7.65 & 13.60 & 42.01 & 42.01 & 295.10 \\
\hline UHSBGL-3 & 49.88 & 7.50 & 16.04 & 47.02 & 47.02 & 406.80 \\
\hline UHSBGL-4 & 34.69 & 4.30 & 9.05 & 35.05 & 37.10 & 268.30 \\
\hline UHSBGL-5 & 50.92 & 13.76 & 17.00 & 49.60 & 49.60 & 421.50 \\
\hline UHABGL-6 & 45.00 & 10.77 & 18.00 & 44.31 & 44.31 & 401.80 \\
\hline UHSBGL-7 & 43.90 & 12.00 & 17.65 & 44.88 & 44.88 & 367.20 \\
\hline UHSBGL-8 & 40.04 & 7.00 & 14.75 & 39.75 & 39.75 & 311.10 \\
\hline UHSBGL-9 & 42.55 & 6.75 & 16.40 & 40.88 & 40.88 & 318.50 \\
\hline UHSBGL-10 & 46.62 & 10.45 & 16.25 & 44.17 & 44.17 & 407.60 \\
\hline UHSBGL-11 & 44.26 & 9.95 & 18.75 & 42.97 & 42.82 & 396.00 \\
\hline UHSBGL-12 & 35.72 & 6.40 & 9.95 & 33.83 & 36.26 & 272.70 \\
\hline UHSBGL-13 & 43.80 & 9.40 & 18.60 & 45.03 & 45.03 & 415.10 \\
\hline UHSBGL-14 & 52.29 & 17.15 & 27.75 & 47.91 & 48.32 & 463.35 \\
\hline UHSBGL-15 & 35.15 & 4.75 & 10.06 & 32.97 & 33.22 & 284.40 \\
\hline S.Em \pm & 1.55 & 0.98 & 1.14 & 1.08 & 1.25 & 20.83 \\
\hline $\mathrm{CD}(0.05)$ & 4.70 & 3.00 & 2.60 & NS & NS & 63.20 \\
\hline
\end{tabular}

NS:Non significant

UHSBGL: University of SciencesBagalkot Gaillardia Local 
Table.4 Flowering parameters of various

\begin{tabular}{|l|c|c|c|c|c|c|}
\hline Genotypes & $\begin{array}{c}\text { Number of days } \\
\text { taken for } \\
\text { appearance of first } \\
\text { flower bud (days) }\end{array}$ & $\begin{array}{c}\text { Number of days } \\
\text { taken for 50 per } \\
\text { cent flowering } \\
\text { (days) }\end{array}$ & $\begin{array}{c}\text { Duration } \\
\text { of } \\
\text { flowering } \\
\text { (days) }\end{array}$ & $\begin{array}{c}\text { Shelf life } \\
\text { (hr) }\end{array}$ & $\begin{array}{c}\text { Individual } \\
\text { flower } \\
\text { weight } \\
\text { (g) }\end{array}$ & $\begin{array}{c}\text { Diameter } \\
\text { of disc } \\
\text { (cm) }\end{array}$ \\
\hline UHSBGL-1 & 113.50 & 160.00 & 71.50 & 1.65 & 2.32 & 2.12 \\
\hline UHSBGL-2 & 101.50 & 130.60 & 90.00 & 4.76 & 3.04 & 1.46 \\
\hline UHSBGL-3 & 111.55 & 138.00 & 110.50 & 3.33 & 1.64 & 2.04 \\
\hline UHSBGL-4 & 115.50 & 161.50 & 61.00 & 6.57 & 2.04 & 1.72 \\
\hline UHSBGL-5 & 75.50 & 95.50 & 116.00 & 11.35 & 8.99 & $* 0.00$ \\
\hline UHSBGL-6 & 122.65 & 145.00 & 78.50 & 7.85 & 5.24 & 2.95 \\
\hline UHSBGL-7 & 117.50 & 137.50 & 86.50 & 1.70 & 2.28 & 1.84 \\
\hline UHSBGL-8 & 106.00 & 126.05 & 87.00 & 11.35 & 2.08 & $* 0.00$ \\
\hline UHSBGL-9 & 95.00 & 115.00 & 99.00 & 6.05 & 3.66 & 2.22 \\
\hline UHSBGL-10 & 108.50 & 133.50 & 69.50 & 11.45 & 6.31 & 4.35 \\
\hline UHSBGL-11 & 95.50 & 120.50 & 72.00 & 7.60 & 2.33 & 1.98 \\
\hline UHSBGL-12 & 83.00 & 103.25 & 91.00 & 8.60 & 3.07 & 2.51 \\
\hline UHSBGL-13 & 98.00 & 118.00 & 101.00 & 10.38 & 4.24 & 2.26 \\
\hline UHSBGL-14 & 59.00 & 69.05 & 131.00 & 14.90 & 2.95 & $* 0.00$ \\
\hline UHSBGL-15 & 61.50 & 82.00 & 121.50 & 13.85 & 2.37 & $* 0.00$ \\
\hline S.Em \pm & $\mathbf{4 . 5 1}$ & $\mathbf{5 . 7 8}$ & $\mathbf{4 . 8 0}$ & $\mathbf{0 . 6 8}$ & $\mathbf{0 . 4 4}$ & $\mathbf{0 . 2 0}$ \\
\hline CD (0.05) & $\mathbf{1 3 . 6 9}$ & $\mathbf{1 7 . 5 3}$ & $\mathbf{1 4 . 5 7}$ & $\mathbf{2 . 0 6}$ & $\mathbf{1 . 3 5}$ & $\mathbf{0 . 6 1}$ \\
\hline
\end{tabular}

$*$ No disc $=$ Pompon type

Table.5 Yield parameters of various genotypes of gaillardia

\begin{tabular}{|l|c|c|c|}
\hline \multicolumn{1}{|c|}{ Genotypes } & Number of flowers per plant & Flower yield (kg/plot) & Flower yield (t/ha) \\
\hline UHSBGL-1 & 56.30 & 1.31 & 3.29 \\
\hline UHSBGL-2 & 66.00 & 0.77 & 1.87 \\
\hline UHSBGL-3 & 69.00 & 1.14 & 2.86 \\
\hline UHSBGL-4 & 40.70 & 0.54 & 1.35 \\
\hline UHSBGL-5 & 67.10 & 1.82 & 4.56 \\
\hline UHSBGL-6 & 56.60 & 1.47 & 3.67 \\
\hline UHSBGL-7 & 70.50 & 1.65 & 4.13 \\
\hline UHSBGL-8 & 51.00 & 0.99 & 2.47 \\
\hline UHSBGL-9 & 43.20 & 0.99 & 2.49 \\
\hline UHSBGL-10 & 62.50 & 1.04 & 2.61 \\
\hline UHSBGL-11 & 63.90 & 1.39 & 3.47 \\
\hline UHSBGL-12 & 58.20 & 1.23 & 3.09 \\
\hline UHSBGL-13 & 53.10 & 1.44 & 3.56 \\
\hline UHSBGL-14 & 203.30 & 2.10 & 5.26 \\
\hline UHSBGL-15 & 98.95 & 1.56 & 3.90 \\
\hline S.Em \pm & $\mathbf{8 . 2 1}$ & $\mathbf{1 . 5 6}$ & $\mathbf{0 . 3 8}$ \\
\hline CD $(\mathbf{0 . 0 5 )}$ & $\mathbf{2 4 . 9 2}$ & $\mathbf{4 . 7 4}$ & $\mathbf{1 . 1 6}$ \\
\hline
\end{tabular}


Table.6 Consumer acceptance for loose flower purpose in various genotypes of gaillardia

\begin{tabular}{|l|c|c|c|c|}
\hline Genotypes & Flower colour & Flower shape & Flower size & $\begin{array}{c}\text { Overall } \\
\text { acceptability }\end{array}$ \\
\hline UHSBGL-1 & 2.97 & 3.34 & 2.42 & 3.39 \\
\hline UHSBGL-2 & 2.55 & 2.30 & 1.79 & 1.38 \\
\hline UHSBGL-3 & 2.95 & 3.45 & 3.37 & 3.25 \\
\hline UHSBGL-4 & 3.92 & 3.95 & 4.16 & 3.35 \\
\hline UHSBGL-5 & 4.20 & 4.37 & 4.57 & 4.35 \\
\hline UHSBGL-6 & 1.54 & 2.35 & 3.48 & 1.80 \\
\hline UHSBGL-7 & 1.85 & 2.52 & 4.22 & 1.70 \\
\hline UHSBGL-8 & 3.15 & 3.42 & 2.63 & 2.35 \\
\hline UHSBGL-9 & 2.46 & 3.23 & 3.35 & 3.00 \\
\hline UHSBGL-10 & 4.20 & 4.33 & 2.85 & 4.35 \\
\hline UHSBGL-11 & 4.38 & 3.94 & 4.02 & 4.20 \\
\hline UHSBGL-12 & 2.27 & 2.50 & 4.28 & 1.55 \\
\hline UHSBGL-13 & 2.36 & 3.01 & 4.47 & 3.75 \\
\hline UHSBGL-14 & 4.70 & 3.90 & 4.45 & 4.75 \\
\hline UHSBGL-15 & 4.15 & 3.44 & 3.53 & 3.39 \\
\hline S.Em \pm & $\mathbf{0 . 3 1}$ & $\mathbf{0 . 2 5}$ & $\mathbf{0 . 3 9}$ & $\mathbf{0 . 1 5}$ \\
\hline CD $(\mathbf{0 . 0 5 )}$ & $\mathbf{0 . 9 4}$ & $\mathbf{0 . 7 8}$ & $\mathbf{1 . 1 8}$ & $\mathbf{0 . 4 3}$ \\
\hline
\end{tabular}

Table.7 Consumer acceptance for landscape purpose in various genotypes of gaillardia

\begin{tabular}{|l|c|c|c|}
\hline \multicolumn{1}{|c|}{ Genotypes } & Uniformity & Flowering & Landscape impact \\
\hline UHSBGL-1 & 1.28 & 1.93 & 1.82 \\
\hline UHSBGL-2 & 1.46 & 1.40 & 1.69 \\
\hline UHSBGL-3 & 2.10 & 1.46 & 1.90 \\
\hline UHSBGL-4 & 1.06 & 0.76 & 0.94 \\
\hline UHSBGL-5 & 2.20 & 2.85 & 1.96 \\
\hline UHSBGL-6 & 0.71 & 0.88 & 0.92 \\
\hline UHSBGL-7 & 2.48 & 2.34 & 2.46 \\
\hline UHSBGL-8 & 1.35 & 1.67 & 1.74 \\
\hline UHSBGL-9 & 2.10 & 1.37 & 1.49 \\
\hline UHSBGL-10 & 1.87 & 0.99 & 2.46 \\
\hline UHSBGL-11 & 2.23 & 2.04 & 2.25 \\
\hline UHSBGL-12 & 0.87 & 1.97 & 1.38 \\
\hline UHSBGL-13 & 1.52 & 2.33 & 2.31 \\
\hline UHSBGL-14 & 2.95 & 2.99 & 2.95 \\
\hline UHSBGL-15 & 2.30 & 2.65 & 2.79 \\
\hline S.Em \pm & $\mathbf{0 . 2}$ & $\mathbf{0 . 2 0}$ & $\mathbf{0 . 1 3}$ \\
\hline CD $(\mathbf{0 . 0 5 )}$ & $\mathbf{0 . 6 4}$ & $\mathbf{0 . 6 3}$ & $\mathbf{0 . 4 0}$ \\
\hline
\end{tabular}


The highest flower yield per hectare was recorded in the genotype UHSBGL-14, followed by UHSBGL-5 and (Table 5) whereas, the genotype UHSBGL-4 recorded lowest flower yield. It is clearly visible that existence of relationship between number of flower production per plant and number of branches per plant increase the flower yield per plot. These results are in conformity with the results reported by Bhaskarwar et al., (2016), Girange et al., (2016), Tamut (2013) in gaillardia; Naik et al., (2005), Raghuvanshi and Sharma, (2011) in marigold and by Ajeetkumar et al., (2015) in dahlia.

\section{Consumer analysis for loose flower purpose}

The consumer preference for loose flower purpose, (Table 6) the genotype UHSBGL-14 was more attractive followed by UHSBGL-11 and UHSBGL-10 with respect to flower colour. The flower shape was better in UHSBGL-5 followed by UHSBGL-10, and UHSBGL-14. Flower size was more in UHSBGL-5 followed by UHSBGL-13 and UHSBGL-14. These results are in conformity with the reports of Beeralingappa et al., (2016). Overall appearance was excellent in UHSBGL-14 and UHSBGL-5 followed by UHSBGL-10 and UHSBGL-11. And the genotype UHSBGL-14 and UHSBGL-5 were mostly preferred by the consumers with respect to flower colour, size, shape and overall acceptability

\section{Consumer analysis garden display purpose}

The preference for landscape flower purpose, (Table 7) the genotype UHSBGL-14 and UHSBGL-15 showed more uniformity in plant growth, flowering when compared to other genotypes. And whereas UHSBGL-14 and UHSBGL-15 were found to be very attractive with respect to landscape impact when compared to other genotypes. These results are in conformity with the reports of Harbugh et al., (2002) and Scholellhorn et al., (2005) in gaillardia.

\section{Acknowledgement}

The authors sincerely acknowledge department of Floriculture and Landscape Architecture $\mathrm{COH}$, Bagalkot for providing the facilities.

\section{References}

Anonymous, 1950, The new illustrated gardening encyclopedia, Odhams Press Ltd., Long acre, London, pp. 303.

Bailey, L. H., 1929, The Std. Cyclopedia. Hort. The Mac Millan Company, New York

Beeralingappa, 2016, Morphological characterization of chrysanthemum (Dendranthem agrandiflora Tzvelev) genotypes under central dry zone of Karnataka. M.Sc. Thesis, Univ. Agri. and Horti Sci., Shivamogga, Karnataka

Bhaskarwar, A. C., Jadhav, G. N., Ghube, N. N., Tayade, M. M., and Patekar, T.R., 2016, Performance of different gaillardia genotypes in respect of growth, flowering, quality and yield parameters. I.J.R.B.A vol IV: 2 .

Bharathi, T. U. and Jawaharlal, M., 2014, Evaluation of African marigold (Tagetes erecta L.) genotypes for growth and flower yield under Coimbatore conditions.Ind. J. Ani.Nutri.,7(16): 2197-2201.

Chandrashekar, R. C., Veeranna, P., Reddy, M. R. and Padmaja, G., 2005, Screening of African marigold (Tagetes erecta $\mathrm{L}$.) cultivars for flower yield and carotenoid pigments. Indian J. Hort., 62(3): 276279.

Deepa, I. and Chezhiyan, N., 2002, Evaluation of chrysanthemum cultivars for yield and related traits. South Indian 
Hort., 50(4/6): 444-450.

Girange, R. R., Charjan, S. U., Jadhav, G. N., Bhaskarwar, A. C., Ghube, N. N. and Lambat, A. P., 2016, Evaluation of different genotypes of gaillardia for growth, flowering and yield parameters. Int. J. Agril. Sci. and Res, 6: 1-6.

Harbaugh , B. K. and Kelly, R.O. 2002, Evaluation of marigold cultivars as bedding and landscape plants in central Florida. Hort. Technol. 12:447-484.

Helen, D., Hammond, Richard, K. S., Sandra, B. W. and Jeffrey, G. N., 2007, Evaluation of gaillardia cultivars and ecotypes for landscape performance in North-Central Florida. SNA. Res. conference, 52: 204-209.

Munikrishnappa, P. M., Patil, A. A., Patil, V. S., Patil, B. N., Channappagoudar, B. B. and Alloli, T. B., 2013, Studies on growth and yield parameters of different genotypes of China aster (Callistephus chinensis Nees.). Karnataka J. Agri. Sci., 26 (1): 107-110.

Naik, B. H., Basavaraj, N. and Patil, V. S., 2005, Evaluation and correlation studies in Afrian marigold genotypes. J. Orn. Hort., 7(3-4): 81- 86.

Namita, Singh, K. P., Raju, D. V. S., Prasad, K. V. and Bharadwaj, C.,2008, Studies on evaluation and genetic advance in French marigold (Tagetes patula) genotypes. J. Orn. Hort., 12(1): 30-34.

Narsude, P. B., Kadam, A. S. and Patil, V. K., 2010, Studies on growth and yield attributes of different African marigold genotypes under Marathwada conditions. The Asian J. Hort., 5(2): 284-286.

Parul, P., Rao, V. K. and Shrama, S. K., 2011, Evaluation of different chrysanthemum (Chrysanthemum morifolium) genotypes under mid hill conditions of Garhwal Himalaya. Indian J. Agric. Sci., 81(9): 830-833.

Patil, V., Kulkarni, B. S., Reddy, B. S.,
Kerure, P. and Ingle, A., 2011, Yield and quality parameters as influenced by seasons and genotypes in marigold (Tagetes erecta L.). Res. J. Agric. Sci., 2(2): 344-347.

Raghuvanshi, A. and Sharma, B. P., 2011, Varietal evaluation of French marigold (Tagetes patula L.) under mid-hill zone of Himachal Pradesh. Prog. Agric., 11(1): 123-126.

Schoellhorn, R. 2005, Boost profits with trial gardens. Lawn and Garden Retailer. 4(4): 24-31.

Singh, D., Sen, L. N. and Sindhu, S. S. 2008, Evaluation of marigold germplasm under semi-arid conditions of Rajasthan. Haryana J. Hort. Sci.,32(4): 206-209.

Singh, K. P., Raju, D. V. S., Namitha, N. and Janakiram, T., 2014, Determination of genetic variation for vegetative and floral traits in African marigold (Tagetes erecta L.). Indian J. Agric. Sci., 84(9): 1057-1062.

Simrat, S., Ramesh, K. and Poonam, 2008, Evaluation of chrysanthemum (Dendranthem agrandiflora Tzevlev) open pollinated seedlings for vegetative and floral characters. J. Orn. Hort., 11 (4): 271-274.

Srivastava, R. and Kandpal, K., 2006, Gaillardia. In: S. K Bhattacharjee (ed), advances in ornamental horticulture Vol. I, Pointer Publisher, Jaipur, pp. 294-304.

Suma, V. and Patil, V. S., 2006, Flower quality parameters in daisy (Aster amellusL.) genotypes. Karnataka J. Agric. Sci., 19(3): 653-656.

Tamut, O., 2013, Studies on variability, heritability, correlation and path coefficient analysis in gaillardia (Gaillardia pulchella Foug.). M.Sc. Thesis, Univ. Horti. Sci., Bagalkot, Karnstaka.

Talukdar, M. C., Sangita, M. and 
Bhaskariyoti, S., 2006, Evaluation of chrysanthemum (Dendranthem agrandiflora Tzevlev) cultivars under polyhouse cum rain-shelter and open field conditions. J. Orn. Hort., 9(2): 110-113.

Vikas, H. M., Patil, V. S., Agasimani, A. D. and Praveenkumar, D. A., 2011, Performance and correlation studies in dahlia (Dahlia variabilis L.). I.J.S.N., 2(2): 379-383.

Zosiamliana, J. H., Reddy, G. S. N. and Rymbai, H., 2013, Study on the performance of some varieties of china aster (Callistephus chinensis Ness.) in Andhra Pradesh. Prog. Hort., 45(2): 312-316.

\section{How to cite this article:}

Saniya, Sateesh R. Patil, P. Pavan Kumar and Mahesh, Y.S. 2021. Evaluation of Gaillardia (Gaillardia pulchella Foug) Genotypes for Loose Flower and Garden Display Purpose. Int.J.Curr.Microbiol.App.Sci. 10(02): 3444-3453. doi: https://doi.org/10.20546/ijcmas.2021.1002.380 